\title{
The influence of pre-crop plants on the occurrence of arbuscular mycorrhizal fungi (Glomales) and Phialophora graminicola associated with roots of winter XTriticosecale
}

\section{JANUSZ BŁASZKOWSKI}

\author{
Department of Plant Pathology. Academy of Agriculture. \\ Słowackiego 17, PL-71434 Szezecin, Poland
}

B $\mathrm{ta} 52 \mathrm{k}$ ow $\mathrm{k}$ i J. The infucace of precrop plants on the occurrence of arbusculas mycorthizal fungi (Giomales) and Phialophora graminicola associated with roots of winter XTriticosecale. Acta Mycol. 30 (2) $213-222,1995$

The infuence of four pre-crop plant species on the occurrence of arbuscular mycorrhizal fungal (AMF; Glomales, Zygomycetes) spcres, mycorrhizae, and Phialophora graminicola (Deacon) Walker associated with roots of field-cultivated XTrificosecale Witumack cv. Maino was investigated. The pre-crop plant species were Hordeum vuigare L. Lupinas luteus L. Pisum sativum L., and Vicia fabav, major Harz. Most spores and specics of AMF were found when XTriticosccale was eultivated following $P$, sativurn. Prior cropping with $L$. iutews caused the occurrence of the lowest number of spores among XTriticosecale rocts. Mycorrhizal colcnization of XTriticosecale was highest when planted after P. sativum and lowest when grown after $\boldsymbol{L}$. luteus:

Key words: mycombizal fungi, Phialophora graminicola

\section{INTRODUCTION}

Arbuscular mycorrhizal fungi (AMF) are associated with most cultivated plants, including Secale cereale L. and Triticum aestivum L. (B ł a s z k o w s k i, 1993). $X T$ riticosecale Wittmack is an artificially produced amphiploid of a hybrid between Secale sp. and Triticum sp. ( $\mathrm{T}$ a r k o w s k i, 1989). The latter is a poorer host of AMF than the former species ( $\mathrm{C}$ z a j k ow s k a - S t r z c m s k a, 1988). Both the mycotrophic status of XTriticosecale and its response to AMF is poorly known (B tas z k owski, 1991 a).

Many investigators indicate that AMF may increase plant growth (B t a s zk o w s k i, 1991 a). The main causes of such an influence on plants are the increased root absorptive surface offered by extramatrical hyphae ( $\mathrm{R}$ h o de s, G e r de m a n n, 1975). the use of soil mineral resources being poorly or unavailable for roots of autotrophic plants (H a y $\mathrm{m}$ a n, 1983), and the increased tolerance to physical (A 1len, Cunning ha m, 1983; S ieverding, Toro, 1988), chemical (Gar c i a - R o m e ra, Oc a m p o, 1988; Griffioen, Ernst, 1989), and biological (R os s, 1972; S c hö n beck, 1978) stresses. 
In short season crops, a significant cffect of AMF on plant growth must depend on early infection ( $\mathrm{Harin} \mathrm{i} \mathrm{k} \mathrm{u} \mathrm{m} \mathrm{a} \mathrm{r,} \mathrm{B} \mathrm{a} \mathrm{g} \mathrm{y} \mathrm{a} \mathrm{r} \mathrm{a} \mathrm{j,} \mathrm{1988).} \mathrm{Thus,} \mathrm{this} \mathrm{is} \mathrm{related}$ to inoculum density, which can be increased either through inoculation or through judicial (reasonable) manipulation of agronomic practices (S i c v c r d in g, 1986).

Prior cropping of soils with non-mycorrizal plants can inhibit mycorriza formation in subsequent mycotrophic plants (H a r i n i k u m a r, B a g y a r a j. 1988). In contrast, crops preceded by highly mycotrophic plants usually harhour both greater mycorrhizal infections and more numerous populations of AMF (D o d d et al., 1990; H a rin ikumar, B ag y a raj, 1988).

Phialophora graminicola (Deacon) Walker is a non-pathogenic fungus ( $\mathrm{H}$ old e n, 1976) which may restrict root colonization by Gaeumannomyces graminis (Sacc.) Arx et Olivier var. tritici Walker (D e a c o n. 1973 b; B ta s z k ow s k i. 1990). Like AMF, it probably improves plant nutrition (Cow a n, 1979). Phialophora graminicola has been found to occur commonly in roots of graminaceous plants growing in Poland (B t a s z k ow s k i, 1991 b) and other regions of the world (B a lis, 1970; Deacon, 1973 a; Re a d, Hase I wand te r, 1981).

Phialophora graminicola has highly increased its occurrence following irrigation, but has not shown any marked response to increasing soil nitrogen concentrations (B łas zkow ski, Kos zański, Kac z marc zy k, 1993). However, there is a lack of data concerning the effect of crop rotation on this species.

The aim of this study was to determine the influence of four pre-crop plants on the occurrence of AMF, mycorrhizae, and $P$. graminicola associated with roots of XTriticosecale cultivated subsequently.

Acknowledgement: This research was in part supported by The Commitlee of Scientific Research (gran! no. 6.P2615.043.05).

\section{MATERIALS AND METHODS}

In 1990, a field experiment at the Agricultural Experiment Station Lipki near Stargard Szczeciński was conducted. The following conditions were set up:

- soil - a good rye complex; $\mathrm{pH} 6.3 ; 1.3-1.5 \%$ of humus; and $13-15 \mathrm{mg} 100 \mathrm{~g}^{-1}$ of $\mathrm{P}_{2} \mathrm{O}_{5}$.

- pre-crop plants - barley (Hoderum vulgare) $\mathrm{cv}$. Bielik; yellow lupine (Lupinus luteus) cv. Rada; garden pea (Pisum sativum) cv, Ramir; broad bean (Vicia faba var. major) cv. Grot,

- host plant - XTriticosecale cv. Malno,

- experimental design - split block with four replicates.

- fertilization (kg/ha) $-\mathrm{N}$ as $\mathrm{NH}_{4} \mathrm{NO}_{3}$ at 75 broadcast in random order to the plots: $\mathrm{P}$ at 50 as superphosphate; $\mathrm{K}$ at 50 as $\mathrm{KCl}$.

Myconthizal colonization was determined based on 25 randomly selected plants with roots collected in the milky rape of seeds (stage 11.2-3, after L a r g c, 1954) separately from cach plot. In the laboratory, roots were washed first in a tap water 
for 5 min. Five-centimetre-long root fragments were subsequently cut off from a depth of $5-10 \mathrm{~cm}$ and then divided into $1-\mathrm{cm}$-long segments. Fiftly $1-\mathrm{cm}$-long root segments coming from a particular plot were stained according to the $\mathrm{P}$ h $\mathrm{i} 1 \mathrm{l} \mathrm{i} \mathrm{ps}$ and $\mathrm{H}$ a y $\mathrm{m}$ a n (1970) method to determine mycorrhizal colonization. Additionally, in the same root segements, the proportion of $P$. graminicola was determined. This fungus was identified based on the criteria described and illustrated by D c a c o n (1973 a).

Spores of AMF were recovered from rhizosphere soils by wet sieving and decanting (Gerde ma n n, Nic ols o n, 1963). Soils were collected at the milky ripe stage of plants. Arbuscular fungi were recognized based on their original descriptions, specimens deposited in the collection of the author of this paper, and information obtained from Drs R. E. Koske (University of Rhode Island, U.S.A.), J. B. Morton (West Virginia University, U.S.A.), and C. Walker (U.K. Forestry Commission). Data were processed by a one way analysis of variance. Spore and species density values were $\log$ transformed $[\log (x+1)]$ before statistical analysis. The statistical significance of differences between means was determined using the least significant difference at 0.05 calculated from the Tukey test. The species compositions of spore populations isolated from the root zone of XTriticosecale preceded by four pre-crop plant species were subjected to cluster analysis. Each species was considered a character, and each character had two possible states of presence (coded as 1 ) and absence (coded as 0 ). The distance coefficients were used in cluster analysis by computing Euclidean distances with a single amalgamation rule and raw data based on the computer program STATISTICA for Windows, release 4.5. Scientific names are according to $\mathrm{W}$ a $\mathrm{I} \mathrm{k} \mathrm{e} \mathrm{r} \mathrm{and} \mathrm{T} \mathrm{rap}$ p e (1993). Specimens have been deposited at the Department of Plant Pathology, University of Agriculture. Szczecin.

\section{RESULTS}

From the root zone of XTriticosecale cultivated in four pre-crop treatment, a total of 442 spores representing 12 species in four genera of AMF, were isolated (Tab. 1). Most spores were recovered from under XTriticosecale growing after garden pea (175 in dry soil), followed by cultivation of board bean (164) and barley plants (95). Only eight spores in $100 \mathrm{~g}$ of dry soil were associated with XTriticosecale roots when the plant in the previous growing season was yellow lupine.

The fungi dominating in the XTriticosccalc rhizosphere soils were species of the genus Glomus (Tab. 1). The proportion of spores of this genus in the overall number of spores of all the AMF recovered was $87.3 \%$. The proportion of Glomus spp. was highest when XTriticosecale was preceded by garden pea $(80.6 \%)$.

The dendrogram analysis of the species composition of the AMF revealed (Fig. 1) that populations most closely related were those of garden pea and board bean with a linkage distance value of 1.73 , followed by those representing barley and broad bean ( 2.0$)$ and barley and garden pea (2.24). The least significant correlations were between yellow lupine and garden pea (3.32) and between barley and yellow lupine (2.45). 
Table I

Spore numbers of arbuscular mycorthizal fungal species isolated from the root zone of XTriticosecale preceded by four plant species

\begin{tabular}{|c|c|c|c|c|}
\hline Fungal species & $\begin{array}{l}\text { Hondeur } \\
\text { velgare }\end{array}$ & $\begin{array}{l}\text { Lupinus } \\
\text { luteus }\end{array}$ & $\begin{array}{l}\text { Prsum } \\
\text { sativam }\end{array}$ & $\begin{array}{l}\text { Vicia faba } \\
\text { var. mujor }\end{array}$ \\
\hline Acaulospora $" 6 \mathrm{t}^{\prime+}$ & $0^{a}$ & $0^{a}$ & $15^{b}$ & $11^{b}$ \\
\hline Entrophospera infrequents (Hall) Ames et Sehneider & $\theta^{\mathrm{a}}$ & $\theta^{\mathrm{a}}$ & $4^{3}$ & $0^{\mathbf{a}}$ \\
\hline Glomus caicdoniurn (Nicol et Gerd.) Trappe et Gerd. & $17^{2}$ & $\theta^{\mathrm{a}}$ & $25^{b}$ & $31^{\mathrm{b}}$ \\
\hline Giomus coastrictum Trappe & git & $8^{2}$ & $23^{b}$ & $30^{\mathrm{b}}$ \\
\hline Giomus đorninikii Błaszkowski & $11^{b}$ & $0^{2}$ & $17^{b}$ & $12^{b}$ \\
\hline Glomus etunicaram Becker et Gerd. & $27^{b}$ & $0^{2}$ & $45^{c}$ & $43^{c}$ \\
\hline $\begin{array}{l}\text { Glomus fasciculatum (Thaxter) Gerd, et Trappe } \\
\text { emend. Walker et Koske }\end{array}$ & $0^{2}$ & $0^{\mathrm{a}}$ & 64 & $10^{\mathrm{a}}$ \\
\hline Glomus macrocarpum Tul. et Tul. & $0^{\mathrm{a}}$ & $0^{\mathrm{a}}$ & $5^{a}$ & $0^{a}$ \\
\hline Glomus mictocapum Tul et Tul. & $18^{b}$ & $\theta^{2}$ & $11^{\mathrm{b}}$ & $16^{\mathrm{b}}$ \\
\hline Giomus occultum Walker & $9^{\mathrm{a}}$ & $0^{\mathrm{a}}$ & $9^{3}$ & $4^{x}$ \\
\hline Scutellospora dipurpurescens Morton et Koske & $4^{\mathrm{a}}$ & $0^{2}$ & $1 t^{2}$ & $7 \mathrm{a}$ \\
\hline $\begin{array}{l}\text { Scuteliospora pelhucida (Nicol et Schenck) } \\
\text { Walker et Sanders }\end{array}$ & $0^{2}$ & $0^{2}$ & $4^{4}$ & $0^{\mathbf{a}}$ \\
\hline Total & $95^{h}$ & $8 \mathrm{at}$ & $175^{c}$ & $164^{c}$ \\
\hline
\end{tabular}

Means followed by the same letters are not statistically different by the Tukey test at 0,05 level

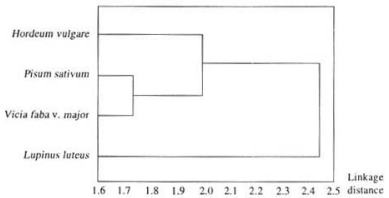

Fig. 1. Dendrograrn illustrating the linkage distance between species compositions of arbuscular fungal populations recovered from the root zone of XTriticosecale preceded by four plant species 
Considering jointly all pre-crop treatments, the AM fungi species dominating in the root zone of $X$ Triticosecale were: $G$. etunicatum, followed by $G$. caledonium, G. constrictum, $G$. microcarpum, and $G$. dominikii (Tab. 1). One unidentified species, i.e., Acaulospora "61", formed abundant spore populations in the root zone of garden pea and board bean. This fungus produces spores singly in the soil, laterally on the neck of a sporiferous saccule. Spores are pale yellow (3A3) to orange (5B8) (K orn crup. W a n s c h c r. 1983): globose to subglobose; (98-) $116(-140) \mu \mathrm{m}$ diam; rarely ovoid; $100 \times 130 \mu \mathrm{m}$, attached to the saccule by a slightly raised collar 8.1-10.5 $\mu \mathrm{m}$ wide $\times$ 3.7-5.0 $\mu \mathrm{m}$ long surrounding a hole $7.5-9.8 \mu \mathrm{m}$ diam. Spore contents at maturity are occluded by a septum formed by continuation of spore-wall growth. Spore wall structure of this fungus consists of seven walls (1-7) which are aggregated in three groups (A. B. C). Group A is composed of three adherent walls (walls 1-3). Wall 1 is evanescent, hyaline, (0.8-) $1.0(-1.3) \mu \mathrm{m}$ thick, usually completely sloughed in mature spores. Wall 2 is laminated, pale yellow (3A3) to orange (5B8), (2.2-) $2.8(-3.9) \mu \mathrm{m}$ thick. Wall 3 is unit, hyaline, (0.5-) $0.7(-0.8) \mu \mathrm{m}$ thick, separable from wall 2. Group B consists of two hyaline, thightly adherent, unit walls (walls 4,5 ), each $0.4-0.6 \mu \mathrm{m}$ thick. Group $\mathrm{C}$ has two adherent hyaline walls (walls 6, 7). Wall 7 is amorphous, $10.0-12.5 \mu \mathrm{m}$ thick in PVLG, (0.8-) $1.1(-1.2) \mu \mathrm{m}$ thick and beetroot purple (13D8) in Melzer's reagent. Spore contents arc of hyaline oil droplets. Sporiferous saccule is hyaline; globose to subglobose; $90-130 \mu \mathrm{m}$ diam; neck is $50-80 \mu \mathrm{m}$ long, tapering from $17-24 \mu \mathrm{m}$ diam at the sacculc to $15-20 \mu \mathrm{m}$ diam at the point of spore attachment. Saccule wall is composed of a hyaline, smooth, 0.8-1.2 $\mu \mathrm{m}$ thick layer. Saccule collapses at maturity and is usually detached among mature spores.

Acaulospora " 61 " is most closely related to A. dilatata Morton, A. longula Spain et Schenck, A. mellea Spain ct Schenck, and A. morrowiac Spain et Schenck due to the similarity in spore colour and the presence of a beaded membranous wall adherent to an amorphous wall in the innermost wall group $\mathrm{C}$ (M or to n. 1994). The features separating Acaulospora "61" from the species mentioned above are spore size and the number of walls in groups $\mathrm{A}$ and $\mathrm{B}$. Acaulospora mellea and A. morrowiae have a 3-walled structure of group A with walls of the same types as in Acaulospora " 61 ". However, the middle group B of spores of the first two species is represented only by one semi-rigid wall, whereas group B in A. mellca has two such walls tightly adherent to each other. Group B of A. Jongula spores also consists of a single wall. Two semi-rigid walls forming wall group B occur in A. dilatata spores, but, like in A. longula, their structural wall is composed of only one laminated wall (vs. three walls in Acaulospora "61").

Of the species dominating (with spores density at and above 40 in $100 \mathrm{~g}$ dry soil), significantly more spores of $G$. caledonium, G. constrictum, G. etunicatum, and $G$. microcarpum were associated with $X$ Triticosecale when grown after garden pea and broad bean than following the cultivation of barley (Tab. 1). The XTriticosecale after yellow lupine treatment was represented only by $G$. constrictum 
spores. Most spores of $G$. dominikii were isolated when the pre-crop was garden pea followed by board bean and barley, but these differences were not statistically significant.

Pisum sativum compared with the other pre-crop plants examined caused in XTriticosecale a significant enhancement of both the degree of mycorrhizal infections and the number of root fragments with vesicles, arbuscules, intramatrical hyphae, and $G$. tenue infections (Tab. 2). XTriticosecale grown on the pea plots also had the greatest percentage of roots with extramatrical hyphae, altough not differing significantly from that regarding the $X$ Triticosecale after bean treatment.

Although the pre-crop plant species did not have any significant effect on the proportion of XTriticosecale roots colonized by $P$. graminicola, this fungus most frequently occurred when $X$ Triticosecale succeeded barley (Tab. 2).

There were significant $(P<0.05)$ correlations between the spore densitics recovered from the root zone of the plant specics examined and their degree of mycorrhizal infection $(r=0.97)$, percentage of roots with vesicles $(r=0.96)$, and intramatrical $(r=0.96)$ and extramatrical hyphac $(r=0.97)$. Additionally, the degree of infection was significantly correlated with the proportion of roots with intramatrical $(\mathrm{r}=0.99, \mathrm{P}<0.05)$ and extramatrical hyphae $(\mathrm{r}=1.00, \mathrm{P}<0.01)$.

$$
\text { Table } 2
$$

Efrect of pre-crop planss on the occurrence of arbuscular mycorrhire, Glomus icnuc, and Phialophara graminicola in XTriticosecale roots

\begin{tabular}{|c|c|c|c|c|}
\hline Specification & $\begin{array}{c}\text { Hordeum } \\
\text { vulgare }\end{array}$ & $\begin{array}{c}\text { Lupinus } \\
\text { metess }\end{array}$ & $\begin{array}{l}\text { Pisum } \\
\text { sativum }\end{array}$ & $\begin{array}{l}\text { Vicia faba } \\
\text { var, major }\end{array}$ \\
\hline Infection degrec* & $0.71^{b}$ & $0,43^{\mathrm{a}}$ & $1.21^{\mathrm{d}}$ & $0.98^{c}$ \\
\hline Vesicles (\%) & $34^{\mathrm{ab}}$ & $16^{2}$ & $44^{b}$ & $37 \mathrm{ab}$ \\
\hline Arbescules (\%) & $11^{a}$ & $12^{2}$ & $21^{b}$ & $14^{a b}$ \\
\hline Intramatrical hyphae (\%) & ga & $31^{\text {ta }}$ & $98^{c}$ & $76^{\mathrm{bc}}$ \\
\hline Extramatrical hyphae $(\tau)$ & $62^{\mathrm{b}}$ & $11^{\mathrm{a}}$ & $75^{\mathrm{c}}$ & $58^{c}$ \\
\hline Glomus tente (\%) & $32^{b}$ & $34^{\mathrm{a}}$ & $91^{\mathrm{c}}$ & $68^{b}$ \\
\hline Phialophora graminicota (\%) & $88^{b c}$ & $8^{3}$ & $6^{2}$ & $14^{3}$ \\
\hline
\end{tabular}

$* 0$ no infection; 1 = low infection areas; highly scattered; 2 = greater infection areas, more tniform; $3=$ roots uniformly infected

Means followed by the same letters are aot statistically different by the Tukey test at 0.05 level

\section{DISCUSSION AND CONCLUSIONS}

The presence of numerous spore populations representing four of the six genera of AMF known supports many reports of the common occurrence of these fungi in agricultural soils (B 1 a $s$ z k o w s k i, 1993). 
In the present study, spores of the genera Entrophospora, Gigaspora, and Sclerocystis were lacking. Entrophospora infrequens (Hall) Ames at Schneider and G. gigantea (Nicol. et Gerd.) Gerd. et Trappe had been revealed in soils of both the Agricultural Experiment Station Lipki and other cultivated sites in Poland, altough in low densities (B ł a s z k ow s k i, 1993). In Poland Sclerocystis rubiformis Gerd. et Trappe has been found so far to be associated only with wild plants (B 1 a s z k o w$\mathrm{s} \mathrm{k} \mathrm{i}$, 1993). Entrophospora infreguens, G. gigantea, and $S$. rubiformis have been reported from cultivated sites of other regions of the world (A $\mathrm{n}$ et al., 1993; B e n t iveng a, Hetrick, 1992; H a mel etal., 1994; J o h ns on etal., 1991; S c hen ck, $\mathrm{K}$ in $10 \mathrm{ch}, 1980$ ). The lack of fungi mentioned above in soils sampled by the author of this paper may result from their, among others, susceptibility to stresses caused by agricultural practices (D o d d, J e f f r i e s, 1989; J a s per et al., 1989; S c he n c k, $\mathrm{S}$ i q u c ir a, O I i v c i r a, 1989), adaptation to other soil conditions ( $D$ a $y$, S y l via, C ollin s, 1987), seasonality of sporulation ( $\mathrm{e} \mathrm{m} \mathrm{m} \mathrm{a,} \mathrm{K} \mathrm{o} \mathrm{s} \mathrm{k} \mathrm{c,} \mathrm{C} \mathrm{a} \mathrm{r-}$ rei r o, 1989; $\mathrm{H}$ a y m a $\mathrm{n}, 1970$ ), and omitting due to excessively low number of collected soil samples (St. J o h n, K o s k e, 1988). F r a n k e and M o r t o n (1984), Ga ze y et al. (1992), and J a s per et al. (1993) showed that sporulation is dependent on a threshold level of mycorrhizal colonization. Thus, the absence of sporulation does not indicate the absence of fungal organism. The absence of spores does indicate, however, that mycorrhizal biomass of detected organisms has reached critical mass for sporulation, and the quantity of spores may provide some measure of fungal fitness.

This and other investigations (B t a s z k o w s k i, 1993; C z a j k o w s k a : - S t r z e m s k a, 1988) provide evidence that garden pea and board bean are good host plants for the rapid build-up of infective propagules of AMF. Most leguminous plants are highly mycotrophic ( $\mathrm{H}$ a r le y, $\mathrm{H}$ a r l e y, 1990; $\mathrm{H}$ a r le y, S m it h, 1983).

The distinctive low number of spores associated with XTriticosecale preceded by yellow lupine supports the results of other investigators that this plant is one of few exceptions among the members of the Leguminosae, being either an autotrophic or rarely forming arbuscular mycorrhiza plant species (C z a jk ow sk a - S $\mathrm{t}$ z e mska, 1988; Harle y, S m it h, 1983).

The predominance of fungi of the genus Glomus in the isolated spore populations corresponds with the results of other investigations conducted in both agricultural soils and sites with natural vegetation (F e r r e r et al., 1989; G i a n i n a z z i-Pcarson et al., 1980; S c h c ck, 1981; Ne mec et al., 1981). This suggests that these fungi are best adapted to a wide range of environmental conditions. A similar conclusion has been drawn by, e.g., B łas zk ow s k i (1993), Gerdem a n and Trap pe (1974), and Mosse, Stribley and LeT a con (1981).

The dominating species in the AM fungi populations recovered were: G. etunicatum, followed by G. caledonium. G. constrictum, G. microcarpum, and $G$. dominikii. Except for $G$. dominikii, the other fungi species are known to occur in agricultural soils of different regions of the world ( $\mathrm{B} \mathrm{ta} \mathrm{s}$ z k o w s k i, 1993). Glomus caledonium and $G$. constrictum were previously found among the species 
dominating in cultivated soils of Poland (B ta szk ow sk i, 1993). Glomus dominikii is a stable colonizer of different plants cultivated at the Agricultural Experiment Station Lipki. However, its incidence in other agricultural sites of Poland is rare (B ta s z k ow s k i, 1993). Recently, this species has been recovered from maritime dune soils of the Słowiński National Park (B 1 a s z k ow sk i, unpubl.).

The higher mycorrhizal colonization of XTriticosecale preceded by the garden pea and board bcan treatment compared with the other two plant species tested correspond with the result discussed above regarding the influence of leguminous plants on sporulation of AMF.

Pisum sativum and Vicia faba var. major significantly increased the proportion of XTriticosecale roots with arbuscules, intra- and extramatrical hyphae, and G. tenue (Greenhall) Hall infections. This suggests that these plants may function as biofertilizers for succeeding crops. Arbuscules are the sites of nutrient exchange (B on $\mathrm{f}$ a n t c - F a s o 10,1984 ). Extramatrical hyphae play a crucial role in the uptake and translocations of nutrients to the host plant (C o o p e r. T in k cr. 1978) and can act as a source of inoculum ( $\mathrm{S}$ y $1 \mathrm{v} \mathrm{i} \mathrm{a,} \mathrm{1992)} \mathrm{as} \mathrm{well} \mathrm{as} \mathrm{improve} \mathrm{the} \mathrm{water}$ relations of the plant ( $\mathrm{H}$ a r d i e, L e y to n, 1981), and increase soil aggregation (Mille r, J as to w, 1990). Glomus tenue has been shown to effectively absorb soil phosphorus (P o w e 11, 1979).

No significant effect of the pre-crop plant species investigated on the occurrence of $P$. graminicola in XTriticosccale roots was found. This fungus is a non-pathogenic parasite inhibiting the development of Gacumannomyces graminis var. tritici (D e a c o n, 1973 b) and improving the nutrient status of plants in a manner similar to that known in AMF (C o w a n, 1979). Phialophora graminicola has been found to be commonly associated with wheat and many other grass species growing in Poland (B ł a s z k o w sk i, 1991 b, B ł a s z k ow s k i, unpubl). The higher incidence of $P$. graminicola following the cultivation of barlcy may indicate some preference of this fungus to members of the Gramineae.

\section{REFERENCES}

A II e n. E. B., C u n in g h a m, G. L. 1983. Effecls of vesicular-arbascular mycorthizae on Distichlis spicata under three salinily levels. New Phytol. $93: 227-236$.

AnZ. O. Hendrix J. W. Hershra a D. E. FerrissR. S. Henson G. T, 1993 The influence of crop rotation and soil fumigation on a myconhizal fungal communily associated with soybean. Mycornhiza 3: 171-182.

$\mathrm{B}$ a I is $\mathrm{C}_{4}$ 1970. A comparative study of Phialophora radicicola, an avirilent fungal roor parasite of grastes and cereais. Ann. Appl. Biol. 66: 59-73.

BentivengaS. P., HetrickB. A. D. 1992, Seasonal and temperature effects on mycorrhizal activity and dependence of cool-and warm-season tullgrass prairic grasses. Can. J. Bot. 70: 1596-1602.

B l as z kow sk i J. 1990. Gaeumannomyces graminis var. tritici, Phialophora graminicola and VA fungi associated with healthy and discased roots of wheat. Phytopath Pol. XI 340-352.

B ł a s z k o w sk i J., 1991 a. Wystepowanie grzybów i mikoryz arbuscularnych (Glomales) oraz ich wplyw na wzrost roslin i reakcje na fungicydy. Zesz. Nauk. AR. Syczec, 140, 1-129. 
B I a s z k ow sk i J. 1991 b. Arbuscular fungi (Glomeles) and Phialophora graminicola (Deacon) Walker associated with roots of some plants of the Gramineac. Phytopath. Pol. 2 (XIV): 35-42.

B I as $z \mathrm{k}$ ow s K i J., 1993. Comparative studies of the oceurrence of arbuscular fungi and mycorrhizae (Glonales) in cultivated soils of Poland. Acta Mycol. 28: 93-140.

B taszkows $\mathrm{k}$ i J., KoszańskiZ, Kaczmarcz y K , 1993. The influence of imigation and nitrogen fertilization on the cccurrence of abuscular mycorthizal fungi and Phialophors graminicola (Deacon) Walker associated with roots of winter wheat (Triticum acstivum L.). Phytopath. Pol. 6 (XVIII): $61-71$.

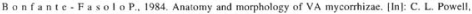
D. J. Bagyaraj, VA Mycorrhiza. CRS Press. Forida. pp. 5-34.

CooperK. M. T in ker P. B., 1978. Translation and iransfer of nutritienis in vesicular mycorrhizas. II. New Phytol. 81:43-52.

C o w a n M, C., 1979. Water use and phosphorus and potassium status of wheat seedling colonized by Gacumannomyces graminis and Phialophora graminicola Plant Soil 5: 1-8.

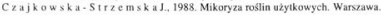

Da y L. D., S y I vi a D. M, Coll in s M. E., 1987. Interactions among vesicular-arbuscular mycorthizat, soil. and landscape position. Soil Sci, Soc. Am. J. 51:635-639.

De a c o n J., 1973 a. Phialophora radicicola and Gacumannomyces graminis on root of grasses and cereals. Trans. Br. Mycol. Soc. $61: 471-485$.

Dea co n J. 1973 b. Factors affecting oceurrence of the Ophiobolus patch disease of turf and its control by Phialophora rudicicola. Pl. Path, 22: 149-155.

D o d d J. C. J e f f r i c s P. 1989. Effect of fungicides on three vesicular-arbuscular mycorrhizal fungi associated with winter wheat (Triticum uestivum L.). Biol. Fertil. Soils 7: 120-128.

Do d d J.C. Arias I. Koomen I. Hay ma n D. S. 1990. The managenent of populations of vesicular-arbuscular mycorrhizal fungi in acid-infertile soils of a savanna ecosystem. I. Plant. Soil 122; $229-240$,

Ferre r R. L., Prik y $\mid$ Z., G r y nd I e r M., V a n c u t a V.. 1989. Natural occurrence of vesicular-arbuscular fungi in grapevine and apple trees. | In |: V. Vancura, F. Kunc. Interrelationships between microorganisms and plants in soil. Proceed Inter. Symp. Acad. Praha. 141-147

Franke M. Morton J. B., 1994. Onlogenetic compariscns of arbuscular mycorrhizal fungi Scutellospora heterogama and Scatellospora peliucida revision of taxonomic character concepts, species descriptions, and phylogenctic hypotheses. Can. J. Bot. 72: 122-134.

Garcia-Romera l., OcampoJ.A. 1988. Effect of the herbicide MCPA on VA mycorrhizal infection and growth of Pisum salivum. Z. Pflanzenernaht. Bodek. 151:225-228.

Gem m a J. N., Kosk e R. E. C a r e ir o M.4 1989. Seasonal dynamies of selected species of VA mycorthizal fungi in a sand dune. Mycol. Res. 92: $317-321$

Gerderman nJ. W. Nicol so a T. H. 1963. Spoces of mycorthizal Endogone species extracted from soil by wet sieving and decanting. Trans. Br. Myeol. Soe, 46: 235-244.

Gerderman IJ. W. Trappe J. M. 1974. The Endogonanceae in the Pacific Northwest. Myc. Memoir. 5: $1-76$

Giantnazzi-Pearson V., Trouvelot A. Morandi D., Marocke R., 1980. Ecological variations in endomycomhizas associated with wild raspberry populations in the Vosges region. Acta Ecol. Plant I: 111-119.

Griffioen W. A. J. Ernst W. H. O. 1989. The role of VA mycorthiza in the heavy metal tolerance of Agrostix cupillaris L. Agric. Ecosyst. Environ. 29: 173-177.

H a me I C., D a 1 p e Y., La pier re C., S i m a r d R. R., S m it h D. L.. 1994. Composition of the vesicular-arbescular fungi poopulation in an old meadow as affected by $\mathrm{pH}$. phosphorus and soil disturbance. Agric. Ecosyst. Environ. 49: 223-231.

Hardie K, L ey to $\mathrm{L}$., 1981. The influence of vesicalar-arbuscular mycorrhiza on growth and water relations of red clover. L. New Phytol. 89: 599-608.

Hariniku mar K. M., B agy a raj D. J., 1988. Effect of erop rotation on native arbuscular mycorrhizal propagules in soil. Plant Scil 110: $77-80$.

H a r I e y J. L. H a rle y E. L., 1990. A check-list of myeorthiza in the British flora-second addenda and errata. New Phytol. 115:699-711.

Ha fle y J. L.S m it h S. E., 1983. Mycorrizal Symbiosis. London. 
H a y $\mathrm{ma} n \mathrm{D}, \mathrm{S}, 1970$. Endogone spore numbers in soil and vesicular-arbuscular mycorrhiza in wheat as influeneed by season and soil treatment. Trans. Br. Mycol. Soc, 554-63.

$\mathrm{H}$ o I d e n J., 1976. Influence of wheat serninal roots by varietes of Phialophora radicicola and Gaumannomyces gramiais. Soil. Biol. Bicch. 8: 109-119.

J a s per D. A., A b bott L. K., R obso n A. D., 1989. Soil disturbance reduces the infectivity of external hyphac of vesicular-arbuscular mycorrhizal fungi. New Phytol. 112:93-99.

J as per D. A., A b b o t $t$ L. K., R o b s o n A. D., 1993. The survival of infective hyphac of vesicular-arbuscular mycorrhizal fungi in dry soil: an interaction with sporulation. New Phytol. 124:473-479.

Johnson N. C., PflegerF. L., Crookston R. K., Si m mons. R., Copeland P.J. 1991. Vesicular-arbuscular mycorrhizas respond to corn and soybean eropping history. New Phytol. 117: $657-663$.

Kornerup A., W a n s c her J. H., 1983. Methuen handbook of coloar. 3rd Ed. Methuen and Co. London.

M ille r R. M., Jastrow J. D., 1990. Hierarchy of root of the mycorrhizal fungal interactions with soil aggregation. Soil Biol. Biochem. 22:579-584

M ort o n J. B., 1994. A problem group of five species in Acualospora. INVAM Newsletter 4: 8.

M osse B.. Strible y D. P. Le T a c on F, 1981. Ecology of mycorrhizae and mycorrhizal fungi. Adv. Microb. Ecol. 5: 137-210.

Nemec.S.. Menge J. A., PI at t R. G, 10 h nson E. L. V, 1981. Vesicular-arbuscular mycorrhizal fungi associated with citrus in Florida and Califarnia and notes on their distributions and ecology, Mycologia 73: 112-127.

Phillips J. M., H a y m a n D. S., 1970. Improved procedures for clearing roots and staining parasitic and vesicalar-arbuscular mycorthizal fungi for rapid assessment of infection. Trans. Br. Mycol. Soc. 55 : $158-161$.

Pow el1C. L., 1979. Inoculation of white clover and ryegrass seed with mycomhizal fungi in unsertile hill soils. N. Z. J. Agric. Res, 22:33\%-339.

Re a d D. J, H a sel w a n d t e r K. 1981. Observations on the mycorhical status of some alpine plant communities. New Phytol. $88: 341-352$.

R hodes L. H., Gerderman n J. W. 1975. Phosphate uptake zones of mycontizal and non-mycorrhizal onions. New Phytol 75: 555.561 .

R o s s J. P., 1972. Influence of Endogone mycorrhiza on Phytophrora rot of soybean. Phytopatholcgy 62 : $896-897$.

S e h e n c k N. C., K i n l o ch R. A., 1980. Incidence of mycorthizal fungi on six field crops in monoculture on a newly cleared wocdland site. Mycologia 72: 445-456.

$\mathrm{Sch}$ en c k N. C. S m it h G. S. 1981. Distribution and occurrence of vesicular-arbuscular mycorthizal fungi on Florida agricultural crops. Soil Crop Sci. Soc. Florida. Proc. 40, 171-175.

Schenck N. C. S i queir a J, O, O liveira E, 1989. Changes in the incidence of VA myeorthizal fungi with changes in ecosystems [In]: V. Vancura, F. Kunc. Interrelationships between microorganisms and plants. Proceed. Intem. Symp. Academy Publishing House of Caechoslovak Academy of Praha, 125-129.

S c hō n be ck F, 1978. Einfluss der endotrophen M ykorrhiza auf die Krankheitsresistenz hỏherer Pflanzen. 2. PflKrankh. PnSchutz 85: 191-196.

Sieverdi a $\mathrm{E}_{4}$, 1986. Reseach model toward pratical application of VA mycorthizal fungi in tropical agriculture. [In]: V. Gianinazzi-Pearson, S. Gianninazzi. Proceed, firct Europ. symp. mycorth. INRA: 475-478. Paris.

Sieverding E. Tor o S. T., 1988. Influence of soil water regimes on VA mycorrhiza. V. Performacnce of different VAM fungal species with cassava. J. Agr. Crop Sci. 161: 322-332.

St. J o h n T.. K o s k e R. E., 1988. Statistical treatment Endogonaceous spore counts. Trans. Br. Mycol. Soc. 91: 117-121.

S y I v i a D. M., 1992. Quantification of external hyphae of vesicular-arbuscular mycorthizal fungi. [In]: J. R. Norris, D. J. Read, A. K. Varma. Techniques for the siudy of mycorrhiza. Methods in microbiology, 24: 53-65. London.

Tarkow s k i C $z, 1989$. Biologia pszenzyta. PWN, Warszawa.

W a I ke r C. T rap p e J. M., 1993, Names and epithets in the Glorales and Eadogonales. Mycol. Res. 97. 339.344. 